\title{
On grade alternation and the illative plural in Lappish
}

In the 43th volume of Finnisch-ugrische Forschungen, Mikko Korhonen (1979) expresses doubts about some of the ideas presented in Sammallahti 1977. This paper is an attempt to answer that criticism.

I did not say that the weak grade of the $x x$ series and the strong grade of the $x$ series merged during the separate development of the western dialects of North Lappish (Korhonen 1979: 245). What I said is that it happened after late Proto-Lappish, i.e. after the split into the major groups of Lappish took place, and I had in mind especially the grade alternation of the Tärna dialect of South Lappish (e.g. Bergsland 1965). Here we have a clear quaternary opposition in stops $(\bar{h} k: h k: h k: k)$ which is considered an impossibility by Korhonen. The half-long consonants in Inari Lappish are another indication of the relative lateness of the merger of $x x$ and $\dot{x}$. Here it took two different courses, either $x x>\dot{x}$ in disyllabic stress groups (Erkki Itkonen's Normaltypus) and the reverse, $\dot{x}>x x$, in trisyllabic ones (Erkki Itkonen's Dehnungstypus). The Inari Lappish case is not conclusive proof but the Tärna one at least comes very close to this, and for me they suffice to show that the merger of $x x$ and $\dot{x}$ happened after the dissolution of late Proto-Lappish.

Preaspiration in stops is dealt with in the traditional way by Korhonen (p. 244-245). The traditional explanation does not, however, account for the occurrence of preaspiration in relatively short double stops which do not alternate with relatively long ones, such as the second components of consonant clusters: lpKld

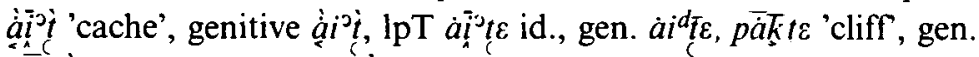
$p \bar{a} \gamma^{\partial} \dot{t} \varepsilon$, lpKld $\varepsilon \mathcal{U}^{d} t \sim \varepsilon \mathrm{v} t$ 'one' gen.sg., lpT $\underset{\wedge}{a \mathrm{v} t a}$ id.; or stops in 
marginal position: lpKld koл'̀ $e^{\delta}$ 'to make run (water)' inf., koл $\mathrm{a} a \supset \grave{t}$ id. sg. 3. prs., lpT van'tta 'stretch' sg.3.prs. (all examples from T.I. Itkonen 1958). These can in no way represent a quantitative equivalent of $\dot{x} x$, which is the only source of preaspiration according to the traditional explanation. Thus it is more probable that both $\dot{x} x$ and $x x$ showed preaspiration. The only difference between the two reflexes of the early Pre-Finnic $x x$ in stops was then the existence of the extra syllabic pulse in $\dot{x} x$, for which Harms has found conclusive material evidence in one of the present dialects of North Lappish (Harms 1975; my own observations are in line with those of Harms). Furthermore it should be borne in mind that some of the dialects of North Lappish (e.g. that of Skånland) lack preaspiration exactly in the reflexes of * $\dot{x} x$ (John Henrik Eira, personal communication).

The real problem here is apparently the development of preaspiration in the $\dot{x}$ case, but this can to some extent be explained by reversing the traditional hypothesis: after $m B>B B$ the distance between ${ }^{*} p p\left(<{ }^{*} \dot{p}\right)$ and ${ }^{*} B B\left(<{ }^{*} m B\right)$ was broadened by introducing preaspiration into * $p p$. The old ${ }^{*} p p p\left(<{ }^{*} p p\right)$ and the new ${ }^{*} h p p\left(<{ }^{*} \dot{p}\right)$ were in complementary distribution in paradigms and no confusion arose. In my explanation, only the preaspiration in $\dot{x}$ needs special treatment, whereas in the traditional explanation both $x x$ and $\dot{x}$ do.

The vowel in illative plural endings (e.g. /njuolajde/ 'arrow', /eatnamijtta/ 'land') seems to require two separate historical explanations, one for West Lappish (at least North and Lule Lappish) and another for Eastern Lappish (Inari Lappish and eastwards). The explanation for the Eastern forms of Lappish may be the one traditionally given for all the Lappish languages, although the origin of $\widetilde{e}$ in the ending is not at all clear (e.g. IpI njuolaid < ${ }^{*}$ n'ōlĕjDĕn 'arrow' ill.pl.), since it cannot be derived by any general sound law or suffixation process. The easiest explanation here would be the exceptional treatment of a contracted vowel, but since we don't have any evidence for ${ }^{*} \overline{\dot{a}} \mathrm{C} e>{ }^{*} i$ (C for consonant) in these forms east of North Lappish this cannot be confirmed, although the ideas of Bergsland (1968: 79) can be used for bridging the gap: he proposes that lpI kiet'an 'into the hand' represents an earlier *kiet'in. Thus, in forms like lpI kàrbàs 'into the boat', ellej 'to the creature' we may have the exceptional dis- 
appearance of a contracted vowel after all, justifying the claim that njuolàid 'into the arrows' derives from earlier * ${ }^{\prime} \bar{o} l e ̋ j p \dot{a} \mathrm{C} \breve{e} n$ (C again for consonant, either ${ }^{*} j$ or, more probably so, ${ }^{*} s$ ).

The possessive forms of ill.pl. in North Lappish contain the same element $-s$ - as those of the ill.sg. (e.g. /njuolajđasa(a)n/ 'into my arrows') and this serves as evidence for positioning the corresponding element in absolute declension forms as well: /njuolajđe/ can be

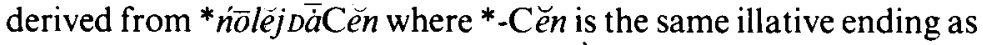
in the absolute singular forms, e.g. ńöle Cĕn 'arrow' ill.sg. protoform. This is the first piece of evidence.

The second derives from the quality of the suffixal vowel. Thirdsyllable word-final /e/ vowels derive from contracted vowels (the exceptions in the possessive suffixes $-/ \mathrm{me} /$ 'our ${ }_{2}$ ' and $-/$ /e/ 'your ${ }_{2}$ ' can be easily explained as analogical), and here the most natural source is, of course, $-(D) \bar{a}+(C) \ddot{e}(n)$ (i.e. the combination of the final vowel of the acc.pl. suffix and the illative suffix). This ${ }^{*} \bar{a} \mathrm{C} e$ then gives ${ }^{*} i(>/ \mathrm{e} /)$ in the same way as in the rare illative singular forms /kahpiire/ 'cap', /ipmiile/ 'God' of the Sodankylä and Kaaresuvanto dialects of North Lappish. These forms are in line with the archaic illative singular forms (here in Konrad Nielsen's orthography) njarigi 'cape', goatta 'hut', bos'šs 'innermost part of hut' of the Tysfjord dialect of Lule (or West) Lappish (Bergsland 1968).

Thus we can propose late Proto(-West)-Lappish illative forms

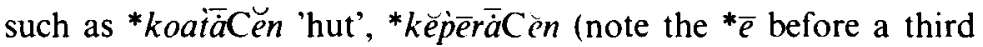

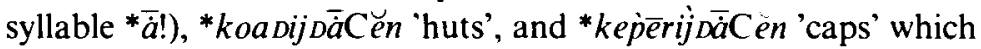
later developed into (Nielsen) *goatta, ${ }^{*}$ gâpperi, ${ }^{*}$ gódiidi, and *gâpperiida. After that, the secondary suffix $-j$ (Nielsen $-i$ ) from $j$ stems (e.g. sullui 'to the island') was added to *goatta giving goattai in all North Lappish dialects (some added -jen from sullujen 'into the island', c.f. lpI suollujăn; note that $\mathrm{lpL}$ jåkkåi 'into the river', goattái 'into the hut' have a different explanation), to "gâpperi in almost all, giving gâpperii, and to göđiidi in the eastern dialects only, giving göđiidii (and later by another suffixation gōtidiida from which by secondary contraction gōtiidâ). Gapperiida did not acquire $-j$ in any of the dialects.

An additional note should be made about the fact that Nielsen's final $-\hat{a}$ in gâpperiidâ is an error, the correct vowel is $-\breve{a}$. The two 
$(-\hat{a}$ and $-\hat{a})$ sound alike, but in the upper Teno dialect of North Lappish for example, we have the ill.pl. form tüeisda (alongside of tuoidDa) which presupposes an earlier *tuoidDa' , c.f. tuoinna 'that' com.sg. This is the third piece of evidence in favor of the contracted vowel from $* \overline{\dot{a}} \mathrm{C} \breve{e}$ for North and Northern Lule Lappish at least. How the illative endings in other forms of Lappish relate to those in North and Lule Lappish lies beyond the scope of this paper, but the evidence suggests strongly that they all derive from a common source, also shared by the Finnic languages, namely *-sěn.

Pekka Sammallahti

\section{REFERENCES}

Bergsland, KNut 1965: Simplification of the Finno-Ugric transcription: Lapp. In

Lauri Posti \& Terho Itkonen (eds.): FU-transkription yksinkertaistaminen. Castrenianumin toimitteita 7. Helsinki 1973.

Bergsland. KNUt 1968: The Grouping of the Lapp Dialects as a Problem of Historical Linguistics. CSIFU. Helsinki.

Harms, Robert T.: Problems in Lapp Phonology. CTIFU 433 439. Tallinn 1975. ITKONEN. ERKKI: Struktur und Entwicklung der ostlappischen Quantitätssysteme. SUST LXXXVIII. Helsinki 1946.

ITKONEN. T. I.: Koltan-ja kuolanlapin sanakirja. I-II. LSFU XV. Helsinki 1958. Korhonen. Mikko: Neues zur Phonologie des Lappischen. FUF 43. 1979.

SAMMALLAHTI.PEKKA:Norjansaaimen Itä-Enontekiön murteen äänneoppi. SUST 160. Vammala 1977. 